\title{
ETHNIC DIVERSITY IN THE PTOLEMAIC FAYUM ${ }^{1}$
}

\begin{abstract}
Summary: This paper will investigate the ethnic conditions of the Ptolemaic Fayum. Society under the Ptolemies was multi-ethnic and multicultural, and besides native Egyptians there were primarily Greeks and Jews. One of the main centres of Greek colonization was the Fayum Oasis, and a great deal of the settlers were Greek soldiers. The uniquely rich documentation from the Fayum offers valuable insight into the ethnic structure of the region. The sources reveal the culture, religion and customs of particular peoples and allow to present their political and economic situation in the state and to examine the relationships between them.
\end{abstract}

Key words: Ptolemaic Fayum, Fayum Oasis, Greek colonization, Egyptians, Jews, ethnic structure

The aim of this paper is to explore the ethnic composition of the Fayum Oasis under the Ptolemies. The ethnicity of the Fayum is important for the social history of Hellenistic Egypt. Establishing a map of the ethnicity of the Fayum could support research on social relationships or the comprehensive analysis of a particular group. The ethnic diversity in the Fayum is perfectly visible among, for example, the temple personnel of many cults in the region, which influenced each other, and frequently a Greek or Egyptian god was worshiped also by other peoples. It could support research on the personnel of temples of all cults attested in the Fayum.

The Fayum is a depression located in the desert $c a .100 \mathrm{~km}$ southwest of Cairo and west of the Nile and presently covers about $2000 \mathrm{~km}^{2}$. In antiquity, the Fayum was

The Project "The Eastern Mediterranean from the 4th century BC until the Late Antiquity" was realized within the International Ph.D. Projects Programme of the Foundation for Polish Science, co-financed by the European Union, Regional Development Fund within the frameworks of Measure 1.2 "Strengthening the Human Potential within the Science Sector" of the Operational Program Innovative Economy.

${ }^{1}$ This paper was originally presented at the 18 th Annual Mediterranean Studies Association International Congress, Athens, Greece, May 27-30, 2015. 
a unique region because of its natural conditions. ${ }^{2}$ The area was supplied with water from the Nile Valley by "Joseph's canal" (Bahr Yusuf), the natural branch of the river which enters into the Fayum Lake (modern Birket Qarun). Moreover, the seasonal floods of the Nile provided fertile mud and enriched the soil in the area. These factors favoured intensive agricultural activity and encouraged settlement in the region. ${ }^{3}$ The first period of the development of the Fayum occurred during the Twelfth Dynasty, especially under the reign of Amenemhet III. ${ }^{4}$ However, the reclamation and the settlement of the area under the early Ptolemies is considered to be one of the most impressive expansions in the history of the ancient world. By reclaiming the Fayum, rulers of the new dynasty were able to establish political control over a new region. Moreover, the favourable natural climate and the fertile lands made the Fayum an important source of revenue for the royal economy. ${ }^{5}$ The total area of cultivated land in the Fayum under the first Ptolemies is estimated between $1200 \mathrm{~km}^{2}$ and $1600 \mathrm{~km}^{2}$, while population estimates in the Fayum vary from 70000 to 100000 people. ${ }^{6}$ The settlement of the Ptolemaic Fayum occurred in phases and had already begun probably under Ptolemy I, but this is not certain because of the lack of sources. Later phases occurred in the mid-third century $\mathrm{BC}$ and again during the second century BC. ${ }^{7}$ There is no doubt, however, that the first settlers were soldiers, thus the settlement of the cleruchs in the Fayum can be linked to periods of the most intense military activity of the Ptolemies. ${ }^{8}$ The conquests of Alexander the Great caused not only military settlement, but also triggered other foreign immigrants seeking economic opportunities to come into the area. A mix of settlers arrived from different regions and settled in the new Ptolemaic foundations, making Egyptian society multiethnic and multicultural.

${ }^{2}$ For a comprehensive illustration of the natural environment of the region, see DERDA, T.: Arsinoites Nomos. Administration of the Fayum under Roman rule. The Journal of Juristic Papyrology 7 , Warsaw 2006, 8-23.

${ }^{3}$ ThOMPSON, D. J.: New and Old in the Ptolemaic Fayum. In Bowman, A. K. - Rogan, E. (eds.): Agriculture in Egypt. From Pharaonic to Modern Times, Oxford 1999, 123-124; MANNING, J. G.: Land and Power in Ptolemaic Egypt. The Structure of Land Tenure. Cambridge 2003, 38-39, 99-100; CLARYSSE, W. - THOMPSON, D. J.: Counting the People in Hellenistic Egypt. Volume 2: Historical Studies. Cambridge 2006, 90.

${ }^{4}$ THOMPSON (n. 3) 124; MANNING (n. 3) 100.

${ }^{5}$ MANNING (n. 3) 104.

${ }^{6}$ BUTZER, K. W.: Early Hydraulic Civilization in Egypt. A Study in Cultural Ecology. ChicagoLondon 1976, $93\left(1300 \mathrm{~km}^{2}\right)$; RATHBONE, D.: Villages, Land and Population in Graeco-Roman Egypt. PCPhS 36 (1990) 103-142 (1 $\left.200 \mathrm{~km}^{2}\right)$; DAVOLI, P.: L'archeologia urbana nel Fayyum di età ellenistica e romana. Naples 1998, $339\left(1600 \mathrm{~km}^{2}\right)$; CLARYSSE-THOMPSON (n. 3) 90-95 (1 $\left.500 \mathrm{~km}^{2}\right)$; for the size of the population, see RATHBONE 130-134; MANNING (n. 3) 107; FISCHER-BOVET, CH.: Counting the Greeks in Egypt. Immigration in the First Century of Ptolemaic Rule. In HollerAn, C. - PUdSEY, A. (eds.): Demography and the Graeco-Roman World: New Insights and Approaches. Cambridge - New York 2011, 138; MOnson, A.: From the Ptolemies to the Romans. Political and Economic Change in Egypt. Cambridge 2012, 37-43.

${ }^{7}$ THOMPSON (n. 3) 108; MANNING (n. 3) 108; Mueller, K.: Settlements of the Ptolemies. City Foundations and the New Settlement in the Hellenistic World. Leuven 2006, 149.

${ }^{8}$ BAgnall, R.: The Origin of Ptolemaic Cleruchs. BASP 21 (1984) 18; THOMPSOn, D. J.: The Exceptionality of the Early Ptolemaic Fayum. In CAPASSO, M. - DAVOLI, P. (eds.): New Archaeological and Papyrological Researches on the Fayyum. Lecce 2007, 307-310. 
The Fayum Oasis is also particularly significant because it belongs to the best documented parts of Ptolemaic Egypt. Ethnic designations appear in a great number of documentary papyri and inscriptions across two languages: Greek and Demotic Egyptian - the two official and most widely used languages of Hellenistic Egypt. Unfortunately, because of the predominance of the Greek documents, we are better informed about Greek life in Ptolemaic Egypt than about Egyptian life. This may lead to the supposition that in the Fayum the majority of the population was Greek-speaking, while recent researches suggest that the foreign immigrants were in a minority with the predominance of native Egyptians. ${ }^{9}$ The statistical analysis of Thompson revealed that Greek settlers constituted about $30 \%$ of the total population of the Fayum in the mid-third century BC. ${ }^{10}$ In addition, sources are unequally distributed across time, which causes problems, as we have far more documentary evidence for the third and mid-second century BC than for any other period in the history of Hellenistic Egypt.

Ethnic labels occur in official or unofficial contexts, depending on the character of the documentation. ${ }^{11}$ In the Ptolemaic period, the ethnic labels were used mainly for formal identification. According to Thompson, from about the mid-third century BC such personal details were required in the Greek legal documents as name, father's name, origin, and occupation. ${ }^{12}$ But determining the ethnic label was also used to establish social position, as the particular ethnicities or occupations had special rights, for example the Jews, who were usually treated in tax registers as privileged Hellenes. ${ }^{13}$ Unofficial papyri, literary works, private letters or religious texts usually provide information about individual perceptions of ethnicity. Because the vast majority of the surviving evidence consists of official documents, it is easier to reconstruct the official view of ethnic identities.

A comprehensive list of peoples with foreign ethnicity in Egypt is provided in Foreign Ethnics in Hellenistic Egypt, volume X of Prosopographia Ptolemaica by Csaba A. Láda, and contains about 170 ethnic labels in Greek and Demotic. ${ }^{14}$ In the volume, besides the ethnic designations of peoples such as Jews, the ethnic labels of individuals derived from Greek poleis (ex. Athenian, Syracusan) or geographical regions, islands, etc. (Kretan, Arkadian) have also been taken into account. The author omitted any expression consisting of a preposition and a geographical term and also excluded ethnic designations derived from literary and magical evidence, because of the questionable historical value and the uncertain dating of these works. ${ }^{15}$ However, the

${ }^{9}$ Clarysse-Thompson (n. 3) 92-102; Mueller (n. 7) 23.

${ }^{10}$ ThOMPSON, D. J.: The Multilingual Environment of Persian and Ptolemaic Egypt: Egyptian, Aramaic, and Greek Documentation. In BAGNALL, R. S. (ed.): The Oxford Handbook of Papyrology. Oxford 2009, 401.

${ }^{11}$ LÁDA, CS. A.: Ethnicity, Occupation and Tax-Status in Ptolemaic Egypt. EVO 17 (1994) 183.

${ }^{12}$ P. Rev. VII 3-4; THOMPSON, D. J.: Hellenistic Hellenes: The Case of Ptolemaic Egypt. In MALKIN, I. (ed.): Ancient Perceptions of Greek Ethnicity. Washington 2001, 304-305.

${ }^{13}$ Clarysse, W.: Some Greeks in Egypt. In Johnston, J. H. (ed.): Life in a Multi-Cultural Society: Egypt from Cambyses to Constantine and beyond [SAOC 51]. Chicago 1992, 52; CLARYSSETHOMPSON (n. 3) 147-148.

${ }^{14}$ LÁDA, Cs. A.: Foreign Ethnics in Hellenistic Egypt [Prosopographia Ptolemaica X]. Leuven 2002.

${ }^{15}$ LÁdA (n. 14) XXXV. 
ethnic designations are quite problematic. In principle, the distinctions between the ethnic groups occupying Egypt are clearly visible under the first Ptolemies, but from the end of the third century and from the beginning of the second century $\mathrm{BC}$ the diversity of ethnic labels had declined. ${ }^{16}$ This may indicate a decrease in the number of arriving immigrants in later periods or the abandoning of ethnic labels by settlers, for example, as a result of acculturation. On the other hand, the variety and frequency of the ethnic labels in the middle of the third century reflect the condition of surviving sources, as we are better informed about that period. Thus, the scarcity of evidence for later decades of the Ptolemaic rule may have caused some of the ethnic designations to remain unknown. It should also be taken into account that the self-definition was often different from the ethnic labels applied, for example for administrative purposes. Thus, 'official' ethnic designations of individuals may refer either to their real origin or the origin of their ancestor, or to a fiscal status often based on occupation. Accordingly, for example, Hellenes appearing in tax lists might indicate both Greek origin and non-Greeks, whose occupation placed them in this fiscal category, or even non-Greek women who married a Greek. ${ }^{17}$

Although, the evidence is too scarce for a statistical analysis, it is possible to map the provenance of immigrants in the Fayum on the basis of the ethnic designations attested in official documents. The ethnic designations collected in the Prosopographia Ptolemaica $\mathrm{X}$ are suggestive of the frequency of particular groups of foreign immigrants. Approximately 115 designations are labelled for the Ptolemaic Fayum. According to the number of attested individuals (both men and women), the following belong to the most frequent ethnic designations in the Fayum during the Ptolemaic period: Macedonians (245), Hellēnes (127), Persians (124), Thracians (84), Jews (64), Cyrenians (40), Arabs (32), Thessalians (19), Athenians (16), Achaeans (13). Other less numerous groups are for example: Arcadians, Cretans, Syrians (9), Syracusans (6), or Boeotians (5). This is not a complete picture, as I have omitted ethnic labels with fewer than five people attested. However, it is clearly visible that the largest group of settlers are Greek-speaking people from regions into which Greek culture had spread during earlier periods. Among the sources collected in PPX ethnic designations are attested in two different forms, as a single label, for example "Persian", and sometimes as "Persian of the epigone". The expression "of the epigone" (or the Egyptian equivalent ms n Kmt 'born in Egypt') following an attested ethnic origin probably designates the offspring of a foreign soldier, who had not yet joined the army. ${ }^{18}$ However, the numbers I have mentioned above consist of ethnic labels, with and without this expression.

Onomastics can also be used on a wider scale as an ethnic criterion. It is worth considering both toponyms and names of individuals attested in Greek and demotic sources. An ethnic snapshot of the Fayum Oasis is revealed by the names of the villages there. Fayumic settlements such as Samareia, Syron Kome (literary meaning:

${ }^{16}$ THOMPSON: Hellenistic Hellenes (n. 12) 304; MUELLER (n. 7) 168

${ }^{17}$ THOMPSON: Hellenistic Hellenes (n. 12) 303-305; MUELLER (n. 7) 177.

${ }^{18}$ VANDORPE, K.: Persian soldiers and Persians of the Epigone: Social mobility of soldiers-herdsmen in Upper Egypt. APF 54 (2008) 87-108. 
'The place of Syrians') or Arabon Kome ('The place of Arabs') provide information about the ethnic background of the largest proportion of the inhabitants. ${ }^{19}$ In the Fayum toponyms such as Arsinoe, Philadelphia or Theadelphia also occur, which refer to dynastic names and are obviously connected with a dynastic settlement. ${ }^{20}$ This may lead us to suppose that a part of the inhabitants of the settlements were newcomers, especially Greek-speaking people and military settlers.

Names of individuals offer an even more valuable insight into the ethnic structure of the Fayum. Names are commonly present in the documentation, thus Greeks, Egyptians or Jews can largely be identified. When determining ethnicity on the basis of the name of the individual, the name of the father, for example, or also so-called theophoric names may be helpful. It was common practice in antiquity to add the name of the father to an individual's name. Especially in the case of Greek or Jewish names there is no problem in recognising the ethnic origins of their bearers, for example, Dionysodoros son of Athenodoros described himself as Athenian, but based only on his name and the name of his father, it is possible to indicate that he belonged to the Greek-speaking people. ${ }^{21}$ Egyptian names are also not as complicated as they seem. The vast majority of them are theophoric names, so this may serve to identify the particular name as Egyptian. Theophoric names derived directly from the god's name, for example Horos ${ }^{22}$, Petesouchos ${ }^{23}$ are connected with a cult and religion in another way, referring for example to sacred animals devoted to deities. ${ }^{24}$

To a certain extent, religious factors determine naming practices also among the Greeks. Consequently, one of the most reliable ways to identify the ethnicity on the basis of onomastics is to examine the names of priests and other temple staff in the Fayum. Temple workers are among the best documented group in the Fayumic society of the Ptolemaic period. Sources provide information about their life, activities and role in society and the state. Moreover, the bulk of documents were generated by or for persons with priestly titles or associated with temples. On the basis of their practiced religion, we can deduce the ethnic designations of individuals. Sources provide some examples: Pasos, an attested feeder of sacred jackals, involved in the cult of Anoubis, has a clearly Egyptian name referring to the Egyptian god Shu, ${ }^{25}$ or the military officer Elazar, son of Nikolaos, and his wife Eirenes making an offering to the synagogue, which supports the claim that they were Jews. ${ }^{26}$

Unfortunately, we cannot always use this pattern. Many religions in the region started to influence each other, so it is not always the case that native inhabitants or immigrants believed only in their ethnic gods. In principle, names of individuals have to be treated with extreme caution when used for the purpose of determining ethnic

${ }^{19}$ THOMPSON-CLARYSSE (n. 3) 90-92; MUELLER (n. 7) 23-30.

${ }^{20}$ MuelLer (n. 7) 3-4.

${ }^{21}$ I. Fayoum II $136=$ I. Prose $39=$ C. Ord. Ptol. $70=$ Rigsby, Asylia $225=S B 15219=$ SB $36155=$ $S E G$ XLVI $2263[225]$ descr. $=C G C 33037=$ OGIS $2736=$ P. Fay. p. 47-50 $=$ SEG XL 1561 descr.

${ }^{22}$ I. Fayoum I $83=S B 89817=S E G$ XX 648

${ }^{23}$ I. Fayoum III $196=S B 1010703=$ SEG XXIV 1202

${ }^{24}$ ClARYSSE-THOMPSON (n. 3) 333.

${ }^{25}$ I. Fayoum I $98=S B 1.5796=S E G$ XX 647

${ }^{26}$ I. Fayoum III $206=S B 1.27=S B 36218=C I J$ II 1531. 
origin. From the Fayum we have a large collection of Egyptian names transcribed in Greek. For example, the aforementioned Pasos, attested in Greek inscriptions, is the transcribed form of the Egyptian name ${ }^{27}$ Because Ptolemaic administration used two official languages we also have to deal with the bilingual documents in which bilingual names occurred. An inscription form Krokodilopolis may serve as an example, where it is indicated that Eirene and Theoxena, daughters of Demetrios, also bore Egyptian names, Nephersouchos (referring to the god Souchos, literary meaning: 'Souchos is god') and Thaues. ${ }^{28}$ Another problem is that names are often not mentioned at all or are lost. Moreover, many of them reflect popular trends in giving personal names. For instance, Greek names in Egyptian families imply some degree of Hellenization. Thus, the use of dynastic names (Arsinoe, Ptolemaios) was quite common among Egyptians, as a way of expressing loyalty to the Ptolemaic regime. ${ }^{29}$ Consequently, in many cases there is considerable difference between the origin of a name and the bearer's real ethnic designation.

In conclusion, the Hellenistic Fayum was a unique region. Under the Ptolemies, besides native Egyptians, the Fayum was inhabited also by other foreign immigrants with the predominance of Greek-speaking people. I believe that research on ethnicity in Ptolemaic Egypt provides an opportunity for the further study of the social history of the Hellenistic world. Primarily, it allows us to analyse the political and economic situation of peoples and individuals occupying Hellenistic Egypt and then examine the differences between the native inhabitants and foreign immigrants.

Joanna Wilimowska
University of Wrocław (Poland)
Poland
joanna.wilimowska@gmail.com

${ }^{27}$ I. Fayoum I $98=S B 1.5796=S E G$ XX 647

${ }^{28}$ I. Fayoum I $2=S B 11567=$ Chrest. Wilck. $51=$ SEG XXVI 1725 descr. $=$ SEG XXXIV 1560 descr.

${ }^{29}$ Clarysse-ThOMPSON (n. 3) 325-326. 